\title{
The natural factors and anthropogenic stressors influence on Chironomidae communities of two north-African wadis
}

\author{
Ceria Hamache ${ }^{1, *}$ (D), Mateusz Płóciennik ${ }^{2}$ (D), Imane Saal ${ }^{1}$ (D) and Abdeslem Arab $^{1}$ (1) \\ ${ }^{1}$ Department of Ecology and Environment, Dynamic Laboratory and Biodiversity, University of Sciences and Technology Houari \\ Boumediene (U.S.T.H.B.), BP 32 El Alia, Bab Ezzouar, Algiers, Algeria \\ ${ }^{2}$ Department of Invertebrate Zoology and Hydrobiology, Faculty of Biology and Environmental Protection, University of Lodz, 12/16 \\ Banacha St. 90-237, Lodz, Poland
}

Received: 6 March 2021 / Accepted: 1 September 2021

\begin{abstract}
Mediterranean streams reveal high biodiversity and play a crucial role for local populations. North African wadis are less known than European streams. Hence, there is a need to explore factors influencing their communities. Chironomid assemblages of the Seybouse and El Kebir-west wadis, located in Algeria, were surveyed between July 2016 and July 2017. Among 28,045 collected larvae, 51 taxa were identified. The obtained results indicate that wadis saprobity, conductivity and $\mathrm{pH}$ vary seasonally. Air temperature and precipitation affect wadis differently in summer and winter. Two gradients driven by altitude define the river continuum: (1) the bottom substrate, from coarse to fine, and water quality, (2) the variety of meso-habitats from natural to anthropogenic. El Kebir-west, as a natural wadi, has unified communities throughout all its length. Communities of Seybouse vary due to the fact that this larger river is strongly influenced by human activity. Water management in Algeria should focus equally on water quality and natural habitats treatment.
\end{abstract}

Keywords: Chironomid / biodiversity / river continuum / north African / Algeria

\begin{abstract}
Résumé - Facteurs naturels et anthropiques influençant les communautés de Chironomidae de deux oueds situés au nord de l'Afrique. Les cours d'eau de la Méditerranée révèlent une biodiversité élevée et jouent un rôle crucial pour les populations locales. Les oueds de l'Afrique du nord sont moins connus que les cours d'eau européens. Par conséquent, il est nécessaire de mettre en évidence les facteurs qui influencent leurs communautés. Une étude sur l'oued Seybouse et l'oued El Kebir-ouest situés dans le nordest d'Algérie entre Juillet 2016 et Juillet 2017 a été menée en utilisant les Chironomidae. Parmi 28,045 larves collectées, 51 taxons ont été identifiés. Les statistiques multivariées indiquent que la saprobité, la conductivité et le $\mathrm{pH}$ des cours d'eau varient selon les saisons. La température de l'air et les précipitations affectent les oueds différemment en été et en hiver. Deux gradients déterminés par l'altitude définissent le continuum fluvial - 1) le substrat de grossier à fin et la qualité de l'eau, 2) la variation des méso-habitats de naturel à anthropique. El Kebir-ouest, cours d'eau naturel, qui a des communautés unifiées sur toute sa longueur. Les communautés de l'oued Seybouse varient en raison du fait que cette plus grande rivière est fortement influencée par l'activité humaine. La gestion de l'eau en Algérie devrait se concentrer uniformément sur la qualité de l'eau et le traitement des habitats naturels.
\end{abstract}

Mots clés : Chironomidae / biodiversité / continuum fluvial / Afrique du Nord / Algérie

\section{Introduction}

Habitat fragmentation due to land use and climate change has been affecting macroinvertebrate community structure and functional characteristics of stream ecosystems in northern

\footnotetext{
*Corresponding author: hamache.ceria@gmail.com
}

Africa (Bonada et al., 2007). The preservation and improvement of the quality of these aquatic environments have therefore become major issues, and necessarily require an understanding of the ecological functioning of these systems. Since biodiversity of aquatic ecosystems is related to environmental conditions and water quality, studying the distribution and variability of organisms that live in these environments is useful for understanding ecosystem 
functioning. Up until now, north African streams (known in north Africa as wadi) have been scantily studied; particularly their ecological aspects are scarcely known (e.g., Lounaci et al., 2000; Chaib et al., 2011).

Chironomids (Diptera, Chironomidae) inhabit all freshwater habitats due to their wide ecological valency (Armitage et al., 1995). Their extraordinary ecological range as a family and their environmental sensitivity at the species level make them useful for assessing and interpreting changes of aquatic ecosystems (Bhattacharya et al., 2006). Knowledge of the Chironomidae of north African streams tends to be neglected in most ecological studies, probably due to their taxonomic complexity (Bazzanti et al., 2008). Over the past decades, knowledge concerning the Chironomidae has gradually developed in Morocco (Kettani and Moubayed, 2018), Tunisia (Boulaaba et al., 2014) and Algeria (Chaib et al., 2011, 2013). Most of these works were mainly devoted to the distribution of Chironomids, but few concerned their ecology.

This paper presents an ecological study on Chironomidae inhabiting Seybouse and El Kebir-west wadis. The study aimed (i) to assess the taxonomic composition, distribution and diversity of Chironomidae in two Mediterranean streams, (ii) to detect the main factors that control the distribution patterns of communities at study sites, and (iii) to determine the key indicator taxa for river continuum gradient of natural and anthropogenic factors.

\section{Study area}

The study was carried out in the Kebir and Seybouse wadis located in north-eastern Algeria (Fig. 1). El Kebir wadi results from the junction of two rivers (Rhumel and Enndja wadis), and flows into the Mediterranean Sea in Sidi Abdealziz. Its length is $60 \mathrm{~km}$. The Seybouse wadi is about $225 \mathrm{~km}$ long and originates from the junction of the Cherf and Bouhamdane wadis and discharge into the Mediterranean Sea in Annaba.

The climate of the Seybouse and El Kebir-west catchments is typically Mediterranean. Rainy periods begin in October and generally last until late April. During the dry season, the stream sectors dry into temporarily disconnected pools. The climatological data of the study regions were communicated by the Office Nationale de la Météorologie (O.N.M.) (2017) of Dar El Beida.

\section{Materials and methods}

\subsection{Field investigation}

A total of 19 sites were sampled monthly at El Kebir-west and Seybouse wadis between July 2016 and July 2017: 110 samples from the Kebir wadi at ten sites (K1-K10) and 99 samples from the Seybouse wadi at nine sites (S1-S9).

The geographical coordinates of the sampling sites were determined with a geographical positioning system (GPS): latitude, longitude, and altitude $(\mathrm{m})$. The following environmental variables were measured in situ for each sampling site using a HANNA multi-parameter probe: water temperature: $T\left({ }^{\circ} \mathrm{C}\right)$, potential hydrogen $(\mathrm{pH})$, salinity (P.S.U), electrical conductivity: $\mathrm{EC}(\mu \mathrm{S} / \mathrm{cm})$ and dissolved oxygen: DO $(\mathrm{mg} / \mathrm{l})$. The measurement of calcium (mg/l), magnesium (mg/l), chloride $(\mathrm{mg} / \mathrm{l})$, nitrite $(\mathrm{mg} / \mathrm{l})$, nitrate $(\mathrm{mg} / \mathrm{l})$ and suspended matter $(\mathrm{mg} / \mathrm{l})$, were performed in a laboratory. Several environmental variables were visually estimated: riparian vegetation and aquatic vegetation (as a qualitative classification $0-3$ where 0 is no vegetation and 3 is the study site covered fully by vegetation), mud, sand, gravel, pebbles, rocks, water pumping/agriculture, urban wastes, and angling activity (in presence-absence scale $0-1$ ), minimum and maximum temperature of the region: $T_{\min }$ and $T_{\max }$ respectively $\left({ }^{\circ} \mathrm{C}\right)$, and precipitation $(\mathrm{mm})$ of the region.

Chironomidae larvae were collected with the other macroinvertebrate taxa at the 19 sampling sites from different substrates, using a Surber net $(60 \mathrm{~cm}$ width, $250 \mu \mathrm{m}$ mesh) (Surber, 1937), and were preserved in 10\% formaldehyde solution. Once sorted, they were transferred to $70 \%$ ethyl alcohol for final conservation in the laboratory.

\subsection{Laboratory processing}

In the laboratory, all material was mounted on permanent slides, under a binocular magnifying glass and using fine forceps, we separated the cephalic capsules from the rest of the body and placed them between slide and coverslip using Dimethyl Hydanto in Formaldehyde (this support allows to mount specimens directly from $70 \%$ ethanol without dehydration) (Brooks et al., 2007). The specimens were deposited in a collection in the Dynamics and Biodiversity Laboratory of the USTHB (Algiers, Algeria).

The identification of the larvae was done at least to the genus level, using the keys described by Cranston (1982), Rossaro (1982), Ferrarese (1983), Nocentini (1985), Klink and Moller Pillot (2003), Brooks et al. (2007), and Andersen et al. (2013). The ecological preferences of collected taxa were mainly based on the works of Vallenduuk and Moller Pillot (2007) for Tanypodinae, Brooks et al. (2007) for Tanytarsini, Moller Pillot (2009a, 2009b) for Chironomini, Moller Pillot (2013) for Orhtocladiinae.

\subsection{Statistical analyses}

The Detrended Correspondence Analysis (DCA) was performed on square-root transformed biological data with detrending by segments and down-weighting rare species to recognise their distribution (linear vs. unimodal). Because the performed DCA revealed long biological data gradients (4.276 on $\mathrm{Ax} 1$ and 4.465 on $\mathrm{Ax} 2$ [SD units]), Canonical Correspondence Analysis (CCA) was selected to compare environmental and biota variable patterns. Due to autocorrelation, $\mathrm{O}_{2} \%$ was excluded from the CCA. The CCA was performed on square-root transformed data with downweighting rare taxa, biplot scaling and inter-species distance. The significance of environmental variables relating to the biota was tested with the Monte Carlo permutation with automatic selection and permutation under full model.

The two streams were divided according to the communities' composition into sections using the CONstrained Incremental Sum-of-Squares agglomerative clustering (CONISS) analysis. To identify taxa characteristics for sections, the Similarity Percentages (SIMPER) analysis was performed on square-root transformed data with Bray-Curtis similarity and cut off at 


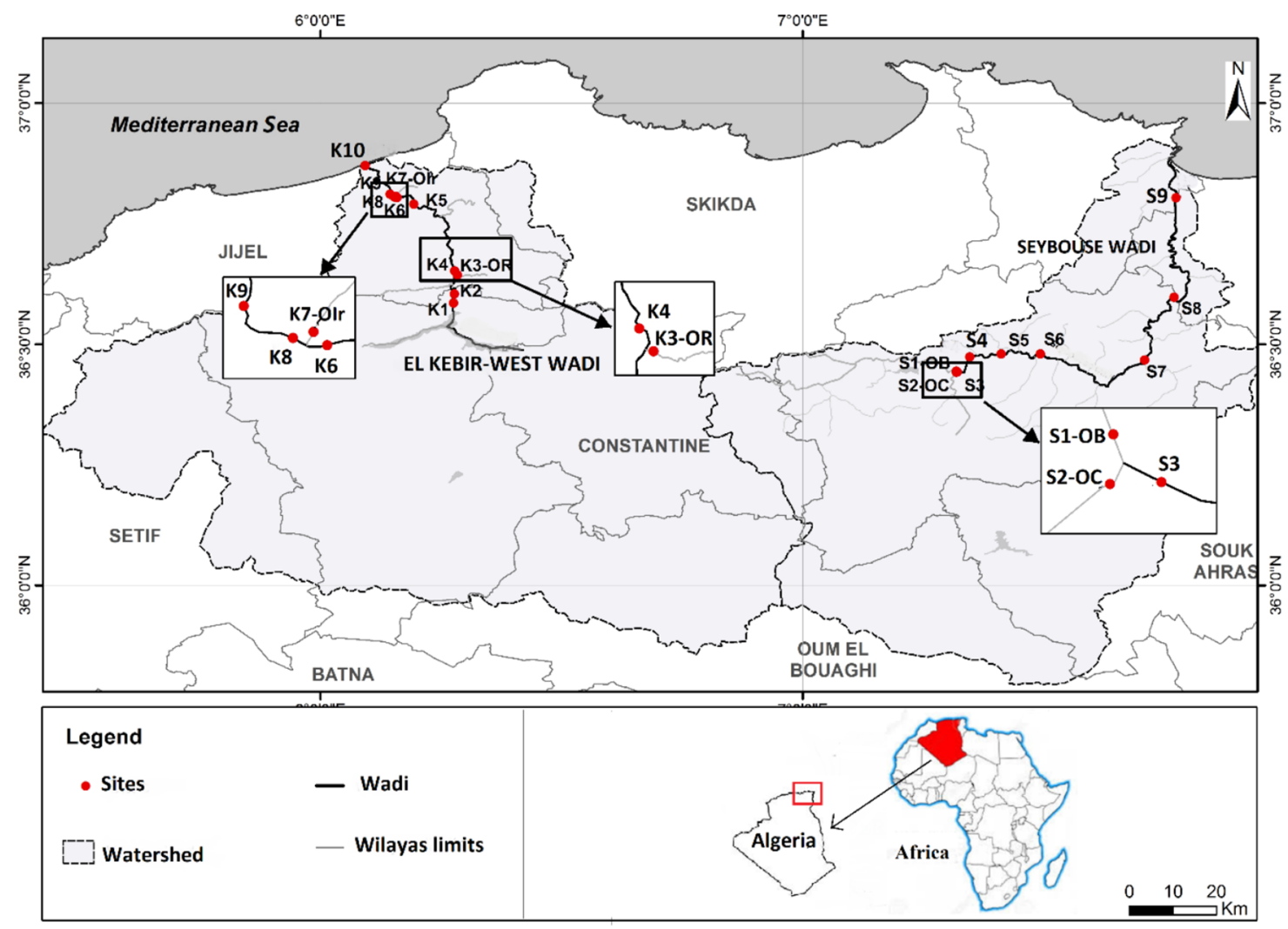

Fig. 1. Location of the study area and sampling sites along the main course of Seybouse and El Kebir wadis (north-eastern Algeria).

$90.00 \%$ for low contributions. The mean Shannon-Wiener Index $\left(H^{\prime}(\operatorname{loge})\right)$ and Pielou's evenness $\left(J^{\prime}\right)$ were calculated for each section of $K$ and $S$ streams. Significance of differences between the sections' mean $H^{\prime}$ (loge) and $J$ ' was tested with Leven's test. The environmental variables that influence sections-combined communities were identified using the Canonical Variate Analysis (CVA) performed with inter-species distance and biplot scaling from a matrix of environmental variables versus species/samples data grouped using CONISS stream sections representing communities from all sections. The significance of environmental variables relating to the sections-combined communities were tested with the Monte Carlo permutation with automatic selection and permutation under full model.

Statistical analyses were carried out using Past, PRIMER 6, Canoco 4.5 and STATISTICA software (Hammer et al., 2001; Clark and Gorley 2001; ter Braak and Šmilauer, 2002; StatSoft Inc., 2015).

\section{Results}

\subsection{Spatial community pattern and its environmental drivers}

Although the CONISS (Appendix III, see Supplementary Material) has divided streams into sections having distinct communities, it indicates a river continuum pattern typical of the two streams. According to Chironomidae community composition, the Kebir-west wadi may be divided into five sections: upper $(U=K 1-2)$, middle sections $\left(M_{1}, M_{2}, M_{3}=K 3\right.$,
K4-6 and K7-8 respectively), and lower $(\mathrm{L}=\mathrm{K} 9-10)$. The Seybouse wadi reveals a similar pattern ( $\mathrm{U}-\mathrm{S} 1, \mathrm{M}_{1}-\mathrm{S} 2-3$, $\mathrm{M}_{2}-\mathrm{S} 4-6, \mathrm{M}_{3}-\mathrm{S} 7$ and $\left.\mathrm{L}-\mathrm{S} 8-9\right)$. The SIMPER analysis distinguishes taxa characteristics for each stream section (Appendix II, see Supplementary material). El Kebir wadi reveals weak taxonomic zonation. Cricotopus bicinctus-type Meigen, Cricotopus annulator Goetghebuer, Rheocricotopus chalybeatus-type Edwards and Chironomus riparius-type Meigen play a dominant role in nearly every section. The Seybouse wadi reveals very clear taxonomic zonation. In Seybouse sections $\mathrm{U}$ and $\mathrm{M}_{1}$, Rheocricotopus chalybeatustype Edwards and Eukiefferiella tirolensis-type Goetghebuer dominate. In section $\mathrm{M}_{2}$, Cricotopus species dominates. In section $\mathrm{M}_{3}$, the dominant taxa are Chironomini - Chironomus plumosus linnaeus and Polypedilum nubeculosum Meigen. The lower (L) section is dominated by Dicrotendipes nervosustype Stäger, Rheocricotopus chalybeatus-type Edwards and Tanytarsus sp Van der Wulp. The values of the H' (loge) and J' indices do not differ statistically between the sections in El Kebir-west wadi. The same is true for the Seybouse wadi (Fig. 2).

The Chironomid communities zonation has its environmental implications (Fig. 3). The CVA K Axis 1 explains 25\% of species data variance and $28.3 \%$ of species-environment relation variance. The CVA K Axis 2 explains $13.3 \%$ of species data variance and $15.1 \%$ of species-environment relation variance. There are nine significant factors influencing the sections' communities. Altitude, rocks and angling activities are positively correlated, while water pumping/agriculture and 
C. Hamache et al.: Knowl. Manag. Aquat. Ecosyst. 2021, 422, 35

Stream K

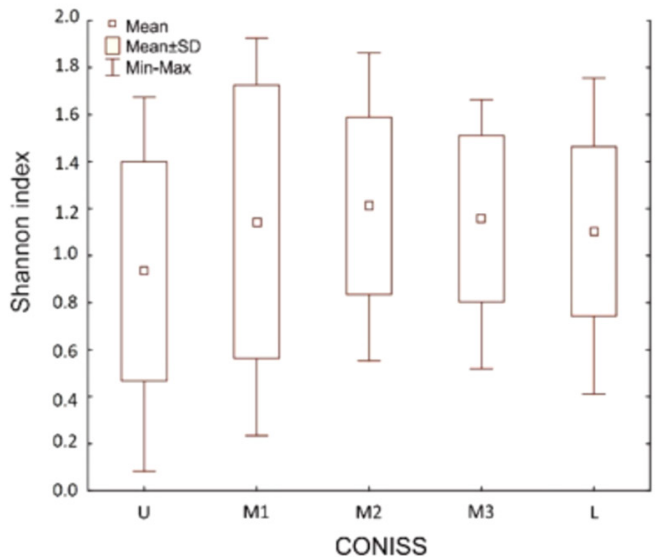

Stream K

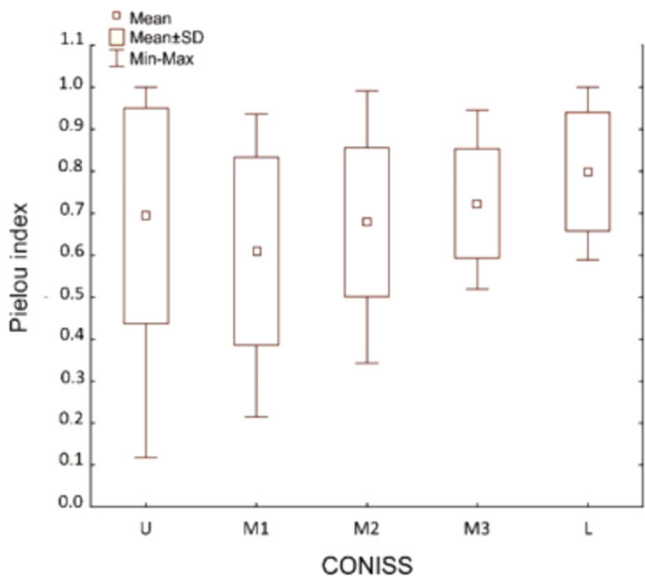

Stream S

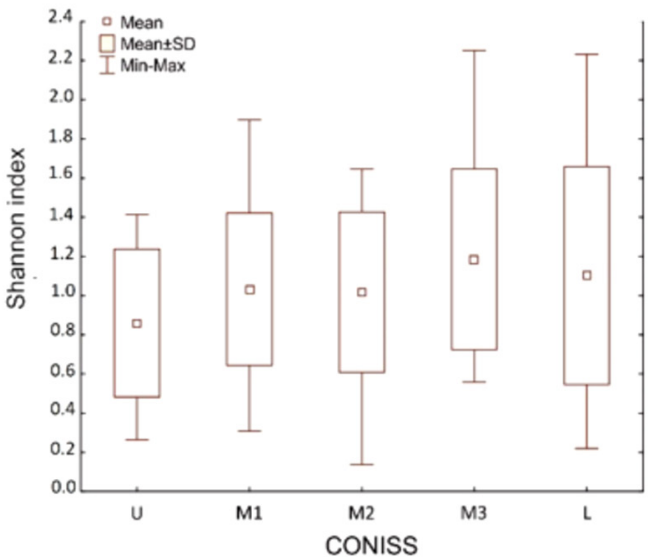

Stream S

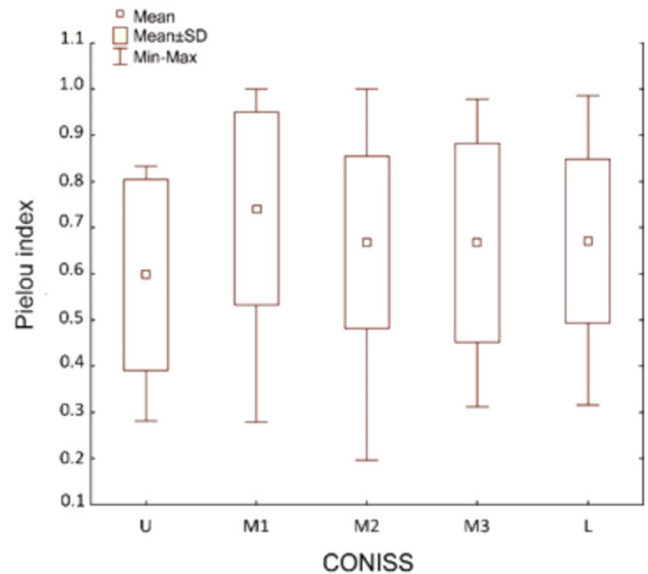

Fig. 2. Box plots of Shannon index (H') and Pielou index (E) in each section of Seybouse and El Kebir-west wadis.
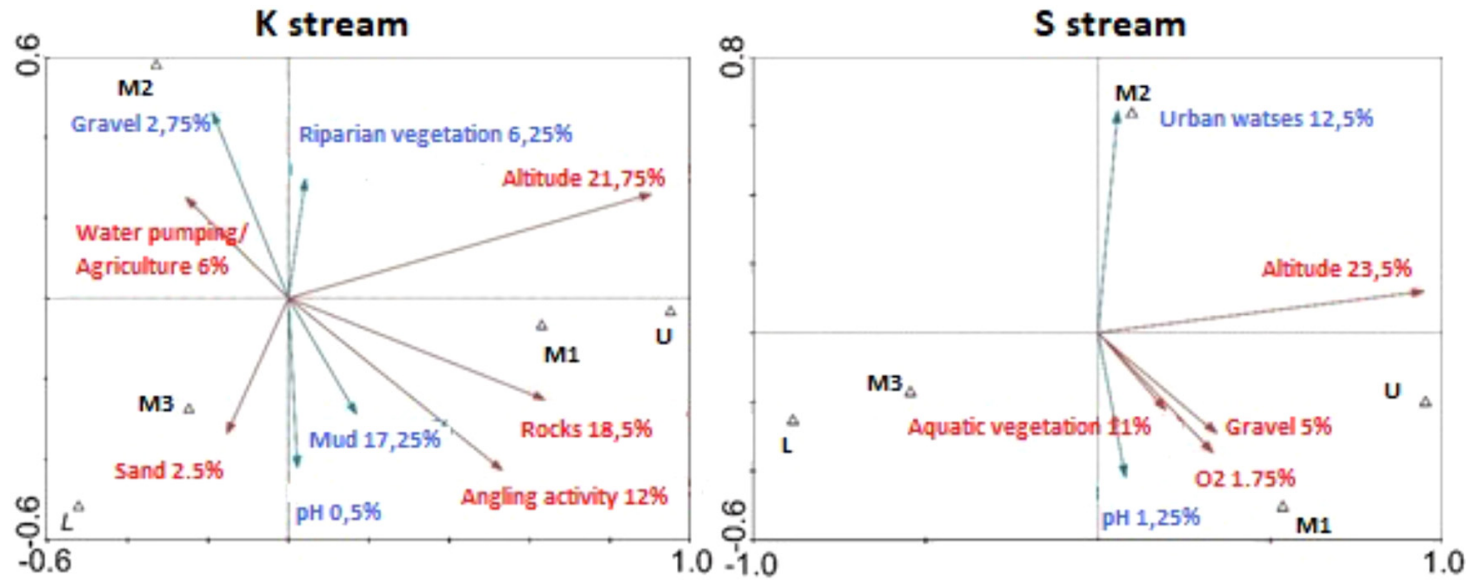

Fig. 3. Results of CVA analysis for the Kebir-west $(\mathrm{K})$ and the Seybouse (S) wadis. Red arrows indicate factors correlated with Ax1, blue arrows indicate factors correlated with Ax 2. Axis 1 is horizontal and Axis 2 vertical. 


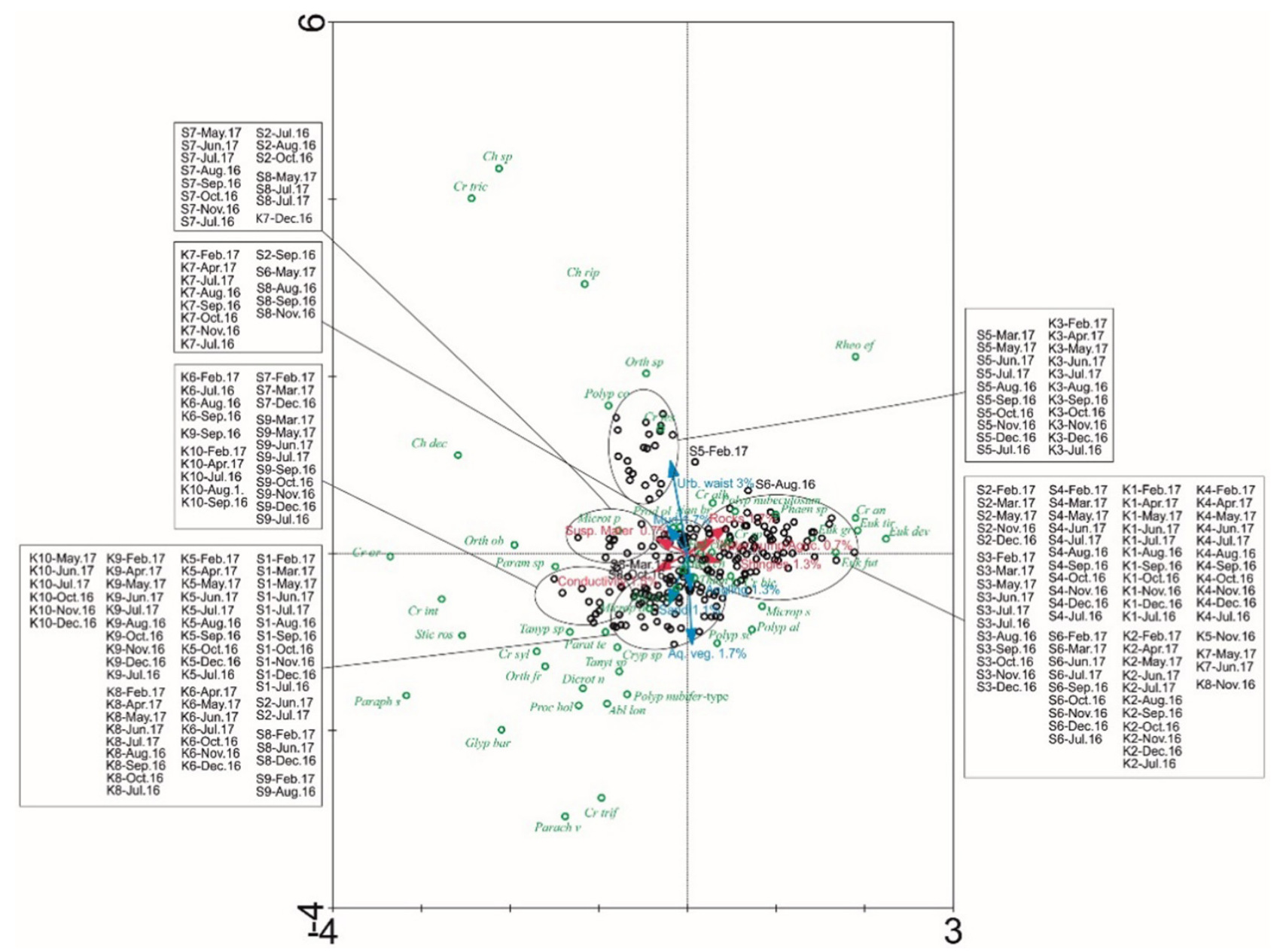

Fig. 4. CCA biplot of samples and environmental variables based on Chironomid assemblages (51 taxa) from the Seybouse and El Kebir-west wadis, north-eastern Algeria. Axis 1 is horizontal and Axis 2 vertical.

sand are negatively correlated with Ax1. Gravel and riparian vegetation are positively correlated, whereas mud and $\mathrm{pH}$ are negatively correlated with Ax2. The upland sections $U$ and $\mathrm{M}_{1}$ have coarse bottom substrates and they are often used for angling activities. The stream's environmental conditions sharply differ from $\mathrm{M}_{2}$ to $\mathrm{L}$ sections. These sections are located in the lowland stream stretch and have a sandy bottom substrate. Section $\mathrm{M}_{2}$ differs from all the others, as it has less mud in the bottom substrate, lower $\mathrm{pH}$, dense riparian bank vegetation and more gravel, especially from the lower $\mathrm{M}_{3}-\mathrm{L}$ sections. The CVA S Axis 1 explains $25 \%$ of species data variance and $35 \%$ of species-environment relation variance. The CVA S Axis 2 explains $14.2 \%$ of species data variance and $20 \%$ of species-environment relation variance. There are only six significant factors influencing the communities in the sections. Altitude, gravel, dissolved oxygen and aquatic vegetation are positively correlated with Ax1. Urban waste is positively correlated, whereas $\mathrm{pH}$ is negatively correlated with $A x 2$. The upper elevated sections $U$ and $M_{1}$ reveal higher oxygen concentration, more gravel and aquatic vegetation than the lowland sections $\mathrm{M}_{3}$ and $\mathrm{L}$. Middle section $\mathrm{M}_{2}$ differs from all the others, as it has more urban waste and lower $\mathrm{pH}$.

\subsection{Habitat complexity and taxa distribution}

The CCA Axis 1 explains $5 \%$ of species data variance and $17.7 \%$ of species-environment relation variance. The Axis 2 explains $4.3 \%$ of species data variance and $15.2 \%$ of speciesenvironment relation variance. There are 17 significant factors influencing sample communities (Fig. 4). Water pumping/ agriculture, gravel and rocks are positively correlated, while conductivity and suspended matter are negatively correlated with Ax1. Urban waste and mud are positively correlated, whereas angling activities, sand and aquatic vegetation are negatively correlated with Ax2. The other significant variables are not correlated with the Axis 1 and 2 and are not illustrated. They are: dissolved oxygen, nitrates, water temperature, pebbles, riparian vegetation, $\mathrm{T}$ min, altitude. The taxa typical of middle and upper middle sites S5 and K3, such as Chironomus spp. Meigen, Rheocricotopus effusus-type Walker, Polypedilum convictum Walker, Orthocladius spp., Cricotopus tricinctus-type Meigen and Cricotopus festivellus Kieffer prefer urban waste to aquatic vegetation and mud to sand bottom substrates. Opposite conditions appear at many sites from the uppermost S1 through the middle $\mathrm{K} 5$ and $\mathrm{K} 6$ to the lower K8, K9 and K10. These conditions are favourable for 
such Chironominae as Glyptotendipes barbipes-type Staeger, Dicrotendipes nervosus-type Stäger, Polypedilum, Cryptochironomus sp. Kieffer, Tanytarsus sp. Van der Wulp, Micropsectra sp. Kieffer, Paratanytarsus tenuis Meigen but also for Tanypodinae, i.e., Ablabesmyia longistyla Fittkau , Procladius (holotanypus) Skuse, Tanypus sp. Upper and middle sites $\mathrm{K} 1, \mathrm{~K} 2, \mathrm{~K} 4$ and S2, S3, S4, S6 are inhabited by taxa preferring more turbulent water where there are rocks on the bottom, many shingles, but also water pumping infrastructure. Those are Eukiefferiella sp1-type Thienemann, Cricotopus annulator Goetghebuer, Phaenopsectra sp. Kieffer and Polypedilum nubifer-type Skuse. Opposite conditions, where there are more suspensions in the water and higher conductivity, appear in the stream's lower sections K10 and S7, S9. There, Cricotopus ornatus Meigen and Cricotopus intersectustype Stæger, Parametriocnemus sp. Goetghebuer and Paraphaenocladius sp. Thienemann, Stictochironomus rosenschoeldi-type and Microtendipes pedellus-type De Geer dominate. Intermediate conditions between these four main types appear mainly at K7. The ubiquistic taxa are Prodiamesa olivacea Meigen and Nanocladius branchicolus-type.

\section{Discussion}

\subsection{Environmental streams zonation}

It may seem that CCA analysis explains very low faunal variability, however $5 \%$ and $4.3 \%$ explaining species data variance for Ax 1 and Ax 2 respectively are not surprising values considering the size of the dataset. As there are 209 samples, 51 biotic and 27 abiotic variables included in CCA, the structure of the dataset is very complicated. That is why CCA conducted for the whole dataset must have low values of explained variance. The same CVA conducted for a simplified dataset containing 27 environmental variables but only 5 biotic variables for each stream (combined to whole river continuum community sections presence/absence U, M1, M2, M3, L) reveals much higher species data variance (CVA K Axis $125 \%$ and CVA S Axis $125 \%$; CVA K Axis $213.3 \%$, CVA S Axis 2 $14.2 \%$ ) just because the structure of the data is much more simple. Nonetheless, CVA cannot replace CCA because CVA is only relevant for river sections' communities but CCA gives detailed relation of all 51 species in all 209 samples to all 27 environmental variables.

The CCA and CVA arranged the investigated communities along two environmental gradients. An upstream/downstream gradient is apparent along Ax 1 of CCA and CVA Ax 1 for S and $\mathrm{K}$ streams. Axis 2 of CCA and CVA (S) shows mainly pollution gradients. The significant variables determine the following typology of the sites studied:

- Sites located in the upper part of the two wadis $\left(\mathrm{S}: \mathrm{U}, \mathrm{M}_{1}\right)$ are characterised by dominant rocky bottom substrate, steep slopes and high water velocity, which makes the water well-oxygenated, less turbid and containing low levels of phosphorus and nitrogen. Altitude is therefore a relevant factor that influences environmental stream zonation performed by CVA, though it does not act as a simple factor but instead combines other variables. With altitude, temperature decreases, while oxygenation increases. This causes more erosion and hinders anthropogenic activities. Boulaaba et al. $(2014,2021)$ indicate that altitude is one of primary factors that determine the composition of midge communities in Tunisia. The coarse substratum and vegetation explain the dominance of Eukiefferiella tirolensis Goetghebuer in upper sections of S stream (SIMPER analysis). According to Cranston et al. (1983), Eukiefferiella larvae are usually found in running water and prefer gravel and stony substrates.

- The remaining sites of $\mathrm{S}\left(\mathrm{M}_{2}, \mathrm{M}_{3}\right.$, and $\left.\mathrm{L}\right)$ are situated in the middle and lower sections. $\mathrm{M}_{3}$ and $\mathrm{L}$ are characterised by a fine substrate and a more or less pronounced mineralisation linked to land use (agriculture) and probably to the geological nature of the land crossed by the waterways. Selvanayagam and Abril (2016) have proven that the geology of watersheds has a huge effect on the chemical composition of water. In the region studied, the ionic composition of the water is strongly influenced by the leaching of agricultural land along the watershed. Increased mineralisation in the downstream sites is linked to an increase in irrigated areas and grazing land. The mineralisation of water in this study involves several forms of pollution: domestic and industrial wastewater discharges (Seybouse wadi), as well as nutrient enrichment by agricultural activities (El Kebir-west wadi). The downstream sites are characterised by low flow water and are very close to the sea, which explains the high levels of salinity and suspended matter. Materials of organic origin are mostly linked to the decomposition of plants (case of S9 and $\mathrm{S} 7$ sites). In estuarine sections (K10), the aquatic biota such as plankton born CPOM can constitute suspended material with particular properties (Germain, 2013).

- Slow flow generates weak oxygenation of the water. These sites shelter species that can tolerate the above-mentioned conditions. These species include: Chironomus spp., which are scarce on stones without mud (Brodersen et al., 1998), and Polypedilum, which is found in a wide range of habitats. It should be noted that Rheocricotopus chalybeatus-type Edwards was recorded throughout the sites of $U, M_{1}$ and $L$ sections in large numbers. Larvae of this species are shredders found in high numbers in the bottom leaf litter. Cricotopus spp. larvae represent the stations in section $\mathrm{M}_{2}$, which are clearly polluted. In fact, it is important to note the significant abundance and frequency of these species in this region. It is also very widely distributed in the temporary pools of eastern Numidia (Zerguine et al., 2009). Nevertheless, the absence of $C$. sylvestris-type Fabricius from Moubayed's studies in Djurdjura streams is surprising but can be explained by the fact that these species are dependent on temperate stagnant environments.

Regarding EL Kebir-west wadi, the conducted CVA (El Kebir) has revealed the existence of a longitudinal granulometric gradient that separates the coarse substrate sites from the fine substrate sites. The SIMPER analysis has shown a very weak taxonomic zonation. This may be due to the homogeneity of the chemical composition of the water resulting from the geological nature of the region. With the exception of $\mathrm{K} 9$ and $\mathrm{K} 10$, which are characterised by a sandy substrate, all the remaining sites have heterogeneous substrates. Representative taxa of El Kebir wadi included 
species of diverse ecological preferences, however, they were mostly associated with running waters and a fine, medium to coarse substrate. They often appeared also in stagnant waters like Chironomus riparius-type Meigen (Moldovan, 1987; own data).

Altitudinal zonation of Chironomids has been studied in Europe since Thienemann (1954) proposed a classification system for European rivers based on their Chironomid taxa. Skoulikidis et al. (2009) provided a detailed environmental classification of lotic waters in Greece. They found that the composition of macroinvertebrate changes longitudinally from the west to the east. Płóciennik and Karaouzas (2014) confirmed these results and revealed that Chironomid assemblages were distinguished into three ecoregions with distinct climatic, geological and hydro-chemical features. However, south-European river zonation may defy popular beliefs. The Evortas River in southern Greece reveals the characteristics of Mediterranean midge community zonation, which is different from the temperate region's river continuum (Karaouzas and Płóciennik, 2016).

Most of the Seybouse sites were exposed to direct industrial or sewage influxes which is consistent with Reggam et al. (2015). Major anthropogenic activities in El Kebir-west wadi catchment influencing its water quality include agricultural activities. The quality of the sites ranged between moderate and good, as was confirmed by Saal et al. (2020). The presented study indicates that anthropogenic factors affect the distribution of Seybouse's Chironomids and promote the abundance of pollution-resistant species. Agriculture did not seem to have any significant influence on sensitive taxa. We recorded a distinct but insignificant increase of assemblage diversity from the upper to lower stream sections. After studying the distribution of Chironomid communities in the Sierra Nevada in southern Spain, Casas and Vilchez-Quero (1993) also came to the conclusion that the upper stream zones revealed lower species richness. The low diversity at high altitude is linked to lower temperature, a reduction in flow, as well as a substrate poor in organic matter.

The higher diversity in S7, K4, K5 and K6 can be explained by the remoteness of these sites from disturbances affecting the survival of Chironomids (e.g., sand extraction, urban waste, etc.), the diversity and density of the biotopes, and especially the availability of resources in these sites. This allows for the occurrence of a variety of species which are generally pollution sensitive. However, in the lower section of both streams, these species are replaced by more thermophilic, more resistant, and less diversified taxa.

\subsection{Chironomidae autecology}

As many as 51 taxa (Appendix I, see Supplementary material) were identified in this study. Most of the composition of the Chironomid assemblage in the Seybouse and El Kebirwest wadis was quite similar to what has been found in other streams of Algeria.

For the first time, a faunistic list of the Chironomids fauna of El Kebir-west wadi is presented along with its distribution. The most common taxa collected in Algeria (Appendix I, see Supplementary material), were part of the assemblage in the Mediterranean regions. The north African Chironomid assemblages are characterised by lower species diversity than that found in European streams due to the harsh local hydroclimatic conditions acting as a restricting factor for the fauna (Arab et al., 2004).

Chironomids, as a heterogeneous group of species with variable responses to environmental gradients (Lencioni and Rossaro, 2005), is claimed to be sensitive to changes along the river continuum in association with elevation, stream order, and channel width (Puntí et al., 2009). In our study, Phaenopsectra sp. Kieffer and Cricotopus annulator Goetghebuer are strongly correlated with the upper rocky stream sites. According to Becker (1995), Phaenopsectra larvae display a preference for stems and leaves of plants, and are less common in dense vegetation (Steenbergen, 1993). They indicate that this species is found only scarcely on stones and sandy bottoms. The results presented here seem to contradict the above-cited observations, as the CCA indicates that Phaenopsectra occurrence in $\mathrm{K}$ and $\mathrm{S}$ was independent from aquatic vegetation. Polypedilum nubifer-type Skuse found here, was an indicator of upstream sites characterised by good oxygenation and turbulent flow. Other research considered this species as one of eurytopic taxa that may be found in diverse habitats (Jacobsen and Perry, 2007).

As far as the response to pollution is concerned, Tanytarsus, Polypedilum and Chironomus species collected at $\mathrm{K}$ and $\mathrm{S}$ wadis were abundant in the polluted sites. Some of species from these genera are known as pollution tolerant (Hare and Shooner, 1995). Representatives of Dicrotendipes nervosus-type Stäger are very resistant to organic pollution. Here, they are found mostly in the downstream sites. They can survive for a short time in water with an oxygen content lower than $1 \mathrm{mg} / 1$ (Rossaro et al., 2007). Low oxygen content may often be the main reason for the absence of Dicrotendipes nervosus, whereas Chironomus species can be present. In fact, among Chironomus species, Ch. riparius Meigen is known to have an extraordinary adaptation capability due to the ability to shift to anaerobic metabolism when necessary. However, Grazioli et al. (2016) reported that Ch. riparius is not the most resistant species to low oxygen content. Specifically, Frank (1983) reported the following order to resistance: Ch. plumosus Linnaeus $>C$. riparius Meigen. The predominance of Chironomini in this type of habitat has also been found in several studies (Yulintine et al., 2008). In addition, Chironomini are thermophilic, which is consistent with our study region.

The most common Tanypodinae in $\mathrm{S}$ and $\mathrm{K}$ dwell in macrophyte habitats and on sandy substrates in slow-current river sections. Their distribution depends on food availability. The type of substrate is also one of the major factors determining the distribution of Tanypodinae (Bijlmakers, 1983). According to the results presented here, Ablabesmyia longistyla Fittkau, Procladius (Holotanypus) Skuse and Tanypus sp. seem to prefer habitats with sandy-silty soils.

Regarding Chironomidae functional feeding groups, the relative abundance of scrapers and shredders was significantly higher in the upstream sites than in the downstream ones (e.g., Cricotopus). The higher relative abundance of shredders in the upper sites may be related to the substantial input of algae and submerged wood from riparian plants (e.g., Rheocricotopus, Orthocladius) (Anderson, 1982). Generally, in the downstream sites, Chironomini are either ditritivorous (e.g., Chironomus), or filter feeders (e.g., Polypedilum and Glyptotendipes). 


\section{Conclusions}

A comparison of the Seybouse wadi with the Kebir-west wadi shows some similarities and some differences in species composition as well as responses to environmental factors. In both rivers, an upstream-downstream gradient is dominant. Natural habitat factors are prevalent in the Kebir-west wadi, while pollution factors are more influential in the Seybouse wadi.

The assemblages related to the tributaries and the upstream sections were characterized by a lower species number, abundance, and diversity, as well as a lower number of indicator taxa compared to the assemblages found in the downstream sites, however, H'(loge) and J' indexes do not differ significantly. The complexity of habitats related to altitude and food availability were the main factors controlling this distribution.

The Mediterranean region ought to draw much greater attention in the near future as a biodiversity hotspot that faces a global water crisis. Expanding studies on Algerian flowing waters, including the Kebir-west and Seybouse wadis, is recommended. New research should cover samples taken over a longer period of time. The next inventory ought to be extended to include other watersheds in order to complete faunistic and ecological studies. The material based on pupal exuviae and adults would contribute to a better understanding of endemism and migration of Chironomidae in the region.

\section{Supplementary Material}

Appendix I. Total abundance of Chironomid species collected in the 19 sampling sites of El Kebir-west and Seybouse wadis.

Appendix II. SIMPER analysis results.

Appendix III. CONISS analysis results.

Appendix IV. Environmental data.

The Supplementary Material is available at https://www.kmaejournal.org/10.1051/kmae/2021034/olm.

Acknowledgements. We are grateful to Robert Sobczyk for calculating Leven's test and preparing Figure 02.

\section{References}

Arab A, Lek S, Lounaci A, Park YS. 2004. Spatial and temporal patterns of benthic invertebrate communities in an intermittent river (North Africa). Ann Limno 40: 317-327.

Andersen T, Cranston PS, Epler JH. 2013. The larvae of the Chironomidae (Diptera) of the Holarctic Region - Contents, forword. $287 \mathrm{p}$.

Anderson NH. 1982. A survey of aquatic insects associated with wood debris in New Zealand stream. Mauris Ora 10: 21-33.

Armitage PD, Cranston PS, Pinder LCV. 1995. The Chironomidae. 1995. Biology and Ecology of Non-biting Chironomids. Chapman \& Hall, London, $572 \mathrm{p}$.

Bazzanti M, Grezzi F, Della Bella V. 2008. Chironomids (Diptera) of Temporary and Permanent Ponds in Central Italy: a Neglected
Invertebrate Group in Pond Ecology and Conservation. Freshw Ecol 23: 219-229.

Becker C. 1995. Ein Beitrag zur Zuckmücken Fauna des Rheins (Diptera: Chironomidae). Thesis Bonn. Aachen: Shaker Verlag, $265 \mathrm{p}$.

Bhattacharya G, Sadhu AM, Majumdar U, Chaudhuri PK, Ali A. 2006. Assessment of impact of heavy metals on the communities and morphological deformities of Chironomidae larvae in the River Damodar (India, West Bengal). Supp Acta Hydrobiolog 8: $21-32$.

Bijlmakers L. 1983. De verspreiding en oekologie van Chironomide larven (Chironomidae: Diptera) in twee vennen in de omgeving van Oisterwijk (N. Br.). Verslag K. U. Nijmegen, 118 p.

Bonada N, Dolédec S, Statzner B. 2007. Taxonomic and biological trait differences of stream macroinvertebrate communities between Mediterranean and temperate regions: implications for future climatic scenarios. Glob Change Biol 13: 1658-1671.

Boulaaba S, Zrelli S, Hedfi A, et al. 2021. Spatio-temporal distribution patterns of Chironomidae communities in the wadis of Northern Tunisia. Br J Biol.

Boulaaba S, Zrelli S, Płóciennik M, Boumaiza M. 2014. Diversity and distribution of Chironomidae (Insecta: Diptera) of protected areas in North Tunisia. Knowl Manag Aquat Ecosyst 415.

Brodersen KP, Dall PC, Lindegaard C. 1998. The fauna in the upper stony littoral of Danish lakes: Macroinvertebrates as trophic indicators. Freshw Biol 39: 577-592.

Brooks SJ, Langdon PG, Heiri O. 2007. The Identification and use of Palaearctic Chironomidae Larvae in Palaeoecology, QRA Technical Guide No. 10, Quaternary Research Association, London, $276 \mathrm{p}$.

Casas JJ, Vilchez-Quero A. 1993. Altitudinal distribution of lotie chironomid (Diptera) communities in the Sierra Nevada mountains (Southern Spain). Ann Limnol 29: 175-187.

Chaib N, Samraoui B, Marziali L, Rossaro B. 2011. Chironomid taxocenosis in a South Mediterranean wadi, the Kebir-East (Algeria). Studi Trent Sci Nat 88: 61-75.

Chaib N, Fouzari A, Bouhala Z, Samraoui B, Rossaro B. 2013. Chironomid (Diptera: Chironomidae) species assemblages in northeastern Algerian hydrosystems. J Entomolog Acarolog Res 45: 4-11.

Clark KR, Gorley RN. 2001. PRIMERv5: User Manual/Tutorial. PRIMER-E Limited, Plymouth, $91 \mathrm{p}$.

Cranston PS. 1982. A key to the larvae of the British Orthocladiinae (Chironomidae). Scient Publs Freshwat Biol Ass 45: 1-152.

Cranston PS, Oliver DR, Saether OA. 1983. The larvae of Orthocladiinae (Diptera: Chironomidae) of the holarctic region - keys and diagnoses. In: Wiederholm T. Chironomidae of the holarctic region. Keys and diagnoses. Part I Larvae. Entomolog Scand Suppl 19: 149-291.

Ferrarese U. 1983. Chironomidi, 3 (Diptera, Chironomidae: Tanypodinae). 26. In: Ruffo S, ed. Guide per il Riconoscimento delle specie animali delle Acque Interne Italiane. CNR Publ., Roma.

Frank C. 1983. Ecology, production and anaerobic metabolism of Chironomus plumosus L. larvae in a shallow lake. Arch Hydrobiol 96: 354-362.

Grazioli V, Rossaro B, Parenti P, Giacchini R, Lencioni V. 2016. Hypoxia and anoxia effects on alcohol dehydrogenase activity and hemoglobin content in Chironomus riparius Meigen, 1804. $J$ Limnol 75: 347-354.

Germain A. 2013. Dynamique des matériaux en suspension (MES) le long de rivières aménagées de montagne: exemple de l'Arc en Maurienne de l'Isère. Thèse de doctorat en Sciences de la Terre. Université de Grenoble, France, 288 p. 
Hammer Ø, David AT Harper, Paul D Ryan. 2001. Past: paleontological statistics software package for education and data analysis. Palaeontolog Electr 4: 9.

Hare L, Shooner F. 1995. Do aquatic insects avoid cadmium contaminated sediments? Environ Toxicol Chem 14: 1071-1077.

Jacobsen RE, Perry SUEA. 2007. Polypedilum nubifer, A Chironomid Midge (Diptera: Chironomidae) new to Florida that has nuisance potential. Florida Entomolog 90: 264-267.

Karaouzas I, Płóciennik M. 2016. Spatial scale effects on Chironomidae diversity and distribution in a Mediterranean River Basin. Hydrobiologia 767: 81-93.

Kettani K, Moubayed JB. 2018. Communities of Chironomidae (Diptera) from four ecological zones delimited by the Mediterranean coastal ecosystems of Morocco (Moroccan Rif). Updated list and faunal data from the last two decades. J Limnol 77: 141-144.

Klink AG, Moller Pillot HKM. 2003. Chironomidae Larvae, Key to Higher Taxa and Species of the Lowlands of Northwestern Europe, ETI, Amsterdam, CD-ROM.

Lencioni V, Rossaro B. 2005. Micro distribution of chironomids (Diptera: Chironomidae) in Alpine streams: an auto ecological perspective. Hydrobiologia 533: 61-76.

Lounaci A, Brosse S, Mouloud SA, Lounaci-Daoudi D, Mebarki N, Thomas A. 2000. Current knowledge of benthic macroinvertebrate diversity in Algerian stream, a species check list of the Sébaou river basin (Tizi Ouzou). Bull Soc Hist Nat Toulouse 136: 43-55.

Moller Pillot HKM. 2009a. Chironomidae Larvae, Biology and Ecology of the Chironomini. Zeist: KNNV Publishing, 270 p.

Moller Pillot HKM. 2009b. A key to the larvae of the aquatic Chironomidae of the North-West European Lowlands, private print, not published, $77 \mathrm{p}$.

Moller Pillot HKM. 2013. Chironomidae Larvae, Volume 3: Biology and Ecology of the Aquatic Orthocladiinae. KNNV Publishing, Zeist, $312 \mathrm{p}$

Nocentini A. 1985. Chironomidi, 4 (Diptera, Chironomidae: Chironominae, larvae). 29. In: Ruffo S, ed. Guide per il riconoscimento delle specie animali delle acque interne italiane. Roma: CNR Publ.

Office Nationale de la Météorologie (O.N.M). 2017. Données climatiques des régions d'étude.

Płociennik M, Karaouzas L. 2014. The Chironomidae (Diptera) fauna of Greece: ecological distributions and patterns, taxalist and new records. Int J Limnol 50: 19-34.

Puntí T, Rieradevall M, Prat N. 2009. Environmental factors, spatial variation, and specific requirements of Chironomidae in Mediterranean reference streams. J North Am Benthol Soc 28: 247-265.

Reggam A, Bouchelaghem H, Houhamdi M. 2015. Qualité PhysicoChimique des Eaux de l'oued Seybouse (Nord-Est de l'Algérie): Caractérisation et Analyse en Composantes Principales
(Physico-chemical quality of the waters of the Oued Seybouse (Northeastern Algeria): Characterization and Principal Component Analysis)

J Mater Environ Sci 6: 1417-1425.

Rossaro B. 1982. Chironomidi, 2 (Diptera, Chironomidae: Orthocladiinae). 16. In: Ruffo S, ed. Guide per il Riconoscimento delle specie animali delle Acque Interne Italiane. Roma: CNR Publ.

Rossaro B, Cardoso AC, Solimini A, Free G, Marziali L, Giacchini R. 2007. A biotic index using benthic macro-invertebrates for Italian lakes. Ecol Indic 7: 412-429.

Saal I, Bouchelouche D, Hamache C, Arab A. 2020. Evaluation of the surface water quality in the Kebir-Rhumel catchment area (northeast Algeria) using biotic indices and physico-chemical analyses. Environ Sci Pollut Res.

Selvanayagam M, Abril R. 2016. Use of benthic macroinvertebrates as a biological indicator in assessing water quality of river Puyo, Pastaza, Ecuador. Am J Life Sci 4: 1-12.

Skoulikidis NTh, Karaouzas I, Gritzalis KC. 2009. Identifying key environmental variables structuring benthic fauna for establishing a biotic typology for Greek running waters. Limnologica 39: $56-66$.

StatSoft Inc. 2015. STATISTICA (data analysis software system), version 12

Steenbergen HA. 1993. Macrofauna-atlas van Noord-Holland: verspreidingskaarten en responsies op milieufactoren van ongewervelde waterdieren. Prov. Noord-Holland, Dienst Ruimte en Groen. Haarlem, 650 p.

Surber EW. 1937. Rainbow trout and bottom fauna production in one mile of stream. Trans Am Fish Soc 66: 193-202.

Ter Braak CJF, Šmilauer P. 2002. CANOCO Reference Manual and CanoDraw for Windows User's Guide: Software for Canonical Community Ordination (Version 4.5). Ithaca: Microcomputer Power.

Thienemann A. 1954. Chironomus. Leben, Verbreitung und wirtshaftliche Bedeutung der Chironomiden. In: Armitage P, Cranston PS \& Pinder LCV. (eds.), The Chironomidae. The biology and ecology of non-biting midges. London: Chapman \& Hall, pp. 107-135.

Vallenduuk HJ, Moller Pillot HKM. 2007. Chironomidae Larvae of the Netherlands and Adjacent Lowlands. General Ecology and Tanypodinae, KNNV Publishing, Zeist, 143 p.

Yulintine L, Wulandari L, Trisliana Y, et al. 2008. Density and biomass of chironomid larvae in a peat channel in central kalimantan, indonesia. In: Proceedings of the International Symposium and Workshop on Tropical Peatland - Restoration and Wise Use of Tropical Peatland: Problems of Biodiversity, Fire, Poverty and Water management. Palangka Raya, 127-1131.

Zerguine K, Samraoui B, Rossaro B. 2009. A survey of Chironomids from seasonal ponds of Numidia, northeastern Algeria. Bollettino di zoologia Agr Bachic 41: 167-174.

Cite this article as: Hamache C, Płóciennik M, Saal I, Arab A. 2021. The natural factors and anthropogenic stressors influence on Chironomidae communities of two north-African wadis. Knowl. Manag. Aquat. Ecosyst., 422, 35. 